\title{
The Other Famous Marks Doctrine
}

\author{
Xuan-Thao Nguyen*
}

I. INTRODUCTION

II. FAMOUS MARKS DoctRINE AND THE CIRCUIT SPLIT ........................ 758

A. Famous Marks Doctrine and Public Policy ............................. 760

B. Famous Marks Doctrine and Bright-Line Rejection ................... 763

III. FAME, USE, AND TERRITORIALITY .................................................. 767

A. Use and Territoriality: Forget Fame …................................... 767

B. Forget Use and Territoriality, but Retain Fame....................... 769

IV. ConClusion: A Legislative, Not Judicial, Solution ................. 771

\section{INTRODUCTION}

Debates on protection for famous trademarks often center around state and federal antidilution laws. Both the old Federal Trademark Dilution Act of 1995 and the new Trademark Dilution Revision Act of 2006 have generated many law review articles and numerous symposia. ${ }^{1}$ The dilution law focuses on trademarks deemed famous within U.S. boundaries. A debate on protection for famous trademarks today is incomplete without a discussion of the other famous marks doctrine. The other famous marks doctrine recognizes marks famous in other countries without actual use in the country where a user adopts the trademark on similar goods and services.

In the age of globalization, both goods and people move across national borders. Moreover, in the age of the internet, people move in cyberspace, transcending physical borders; as people move, they carry with them knowledge about certain trademarks and the associated reputation embodied in those trademarks. A trademark famous outside the United States, but known only to a certain segment of the U.S. population due to peoples'

"Professor of Law, SMU Dedman School of Law. Former IP Associate, Fried Frank Harris Shriver \& Jacobson (NYC); Pryor Cashman Sherman \& Flynn (NYC). This Article was solicited as part of the "International and Comparative Aspects of Trademark Dilution" Symposium. Many thanks to Professors Mark Janis and Peter Yu for the invitation. Special thanks to Erik Darwin Hille and Khai-Leif Nguyen-Hille for their love, patience, and support.

1 See generally Symposium, An Online Symposium on the Trademark Dilution Revision Act of 2006, 105 MICH. L. REV. FIRST IMPRESSIONS 98 (2006); Symposium, Trademark Dilution: Theoretical and Empirical Inquiries, 24 SANTA CLARA COMPUTER \& HIGH TECH. L.J. 449 (2007). A search on Westlaw conducted on May 14, 2008, for articles with titles containing "trademark" and "dilution" from 2006 to May 2008 yielded forty articles. 
movements across borders, prompts a discussion on whether the consuming public should be protected from the likelihood of confusion or fraud. Until now, U.S. courts never have recognized a famous marks doctrine because it is a doctrine that originates from international treaties, such as the Paris Convention for the Protection of Industrial Property ("Paris Convention") ${ }^{2}$ and the Agreement on Trade Related Aspects of Intellectual Property ("TRIPs"). ${ }^{3}$ Although the United States is a signatory to both, these treaties are not self-executing and so do not automatically become a part of U.S. domestic law. This Article will focus on U.S. courts' treatment of the famous marks doctrine, particularly the recent split between the Second and Ninth Circuits on this issue. The split epitomizes two opposite views on fame: use and territoriality. On the one hand, the Second Circuit's approach ignores the fame a foreign mark has attained outside the United States and recognizes trademark rights only if the mark is in use in the United States. On the other hand, the Ninth Circuit embraces the possibility that the fame a foreign mark attains outside the United States may be known by the relevant consumer within the United States, and hence recognizes that trademark rights may exist to protect the consumer from confusion. ${ }^{4}$ Neither approach leads to satisfactory results. The bright-line rejection of the famous marks doctrine by the Second Circuit because of the treaty-based nature of the doctrine places the United States in a position contrary to other countries. ${ }^{5}$ However, the Ninth Circuit's public-policy-based embrace of the doctrine for the purpose of protecting consumers may open doors to a new uncertainty in the requirement of the foreign marks' fame. This Article ultimately concludes that courts should not act as legislative bodies concerning the law on the famous marks doctrine, instead leaving the issue to Congress.

\section{Famous Marks Doctrine AND The CiRCUIT SPLIT}

Trademarks are territorial. Indeed, a trademark symbolizes the goodwill cultivated by the trademark holder within a territory that its consuming public recognizes and from which it expects consistency within that territory. ${ }^{6}$ Under the territoriality principle, a trademark is treated as having

\footnotetext{
2 Paris Convention for the Protection of Industrial Property, Mar. 20, 1883, as last revised at Stockholm July 14, 1967, 21 U.S.T. 1583, 828 U.N.T.S. 305 [hereinafter Paris Convention].

${ }^{3}$ Agreement on Trade-Related Aspects of Intellectual Property Rights, Apr. 15, 1994, Marrakesh Agreement Establishing the World Trade Organization, Annex 1C, Legal Instruments-Results of the Uruguay Round, 33 I.L.M 81 (1994) [hereinafter TRIPs].

${ }^{4}$ See infra Part III.

5 See Alexis Weissberger, Note, Is Fame Alone Sufficient to Create Priority Rights: An International Perspective on the Viability of the Famous/Well-Known Marks Doctrine, 24 CARDOZO ARTS \& ENT. L.J. 739, 768-73 (2006) (discussing the protection available in China, Brazil, and South Africa to famous marks with fames attained abroad, but unregistered within the country extending the protection).
}

${ }^{6}$ Osawa \& Co. v. B\&H Photo, 589 F. Supp. 1163, 1171-72 (S.D.N.Y. 1984). The territoriality doctrine recognizes that: 
an independent existence in each nation in which the trademark is recognized and protected. ${ }^{7}$ Due to this independent existence, ownership of a mark in one country does not provide ownership of and rights to the mark in another country. ${ }^{8}$ One exception to the territoriality principle is the famous marks doctrine of the Paris Convention and TRIPs. ${ }^{9}$ A mark that is famous in a country or countries is also recognized and protected in another country even though the owner of the mark has not registered or used the trademark in that country. 10

[A] trademark has a separate legal existence under each country's laws, and that its proper lawful function is not necessarily to specify the origin or manufacture of a good (although it may incidentally do that), but rather to symbolize the domestic goodwill of the domestic markholder so that the consuming public may rely with an expectation of consistency on the domestic reputation earned for the mark by its owner, and the owner of the mark may be confident that his goodwill and reputation (the value of the mark) will not be injured through use of the mark by others in domestic commerce.

Id.

${ }^{7}$ See Xuan-Thao Nguyen, The Digital Trademark Right: A Troubling New Extraterritorial Reach of United States Law, 81 N.C. L. REV. 483, 489 (2003) (discussing the territoriality doctrine in trademark protection).

8 See Barcelona.com, Inc. v. Excelentisimo Ayuntamiento De Barcelona, 330 F.3d 617, 628 (4th Cir. 2003) ("United States courts do not entertain actions seeking to enforce trademark rights that exist only under foreign law."); E. Remy Martin \& Co., S.A. v. Shaw-Ross Int'l Imports, Inc., 756 F.2d 1525, 1531 (11th Cir. 1985) ("Our concern must be the business and goodwill attached to United States trademarks, not French trademark rights under French law.").

${ }^{9}$ See ITC, Ltd. v. Punchgini, Inc., 482 F.3d 135, 157 (2d Cir. 2007) (explaining the famous foreign mark doctrine):

\begin{abstract}
Article 6bis of the Paris Convention and Article 16(2) of TRIPs requires member states ex officio if their legislation so permits, or at the request of an interested party, to refuse or to cancel the registration, and to prohibit the use, of a trademark which constitutes a reproduction, an imitation, or a translation, liable to create confusion, of a mark considered by the competent authority of the country of registration or use to be well known in that country as being already the mark of a person entitled to the benefits of this Convention and used for identical or similar goods. These provisions shall also apply when the essential part of the mark constitutes a reproduction of any such well-known mark or an imitation liable to create confusion therewith.
\end{abstract}

Id. at 156; see also Paris Convention, supra note 2, at art. 6bis; TRIPs, supra note 3, at art. 16(2).

${ }_{10}$ Punchgini, 482 F.3d at 156-57. The court notes that the purpose of the famous marks doctrine in international treaty law and quotes G.H.C. BODENHAUSEN, GUIDE TO THE APPLICATION OF THE PARIS CONVENTION FOR THE PROTECTION OF INDUSTRIAL PROPERTY 90 (1968) that the doctrine:

[1]s to avoid the registration and use of a trademark, liable to create confusion with another mark already well known in the country of such registration or use, although the latter well-known mark is not, or not yet, protected in that country by a registration which would normally prevent the registration or use of the conflicting mark.

Id. 
Federal trademark law in the United States has long remained silent as to the recognition of famous foreign marks. ${ }^{11}$ Although the Lanham Act has an antidilution provision protecting trademarks deemed famous within the United States, no statutory provision squarely addresses whether a famous foreign mark is entitled to trademark protection in the United States. ${ }^{12}$ Recently, the Second and Ninth Circuits have rendered decisions on U.S. protection for famous foreign marks, adopting opposite approaches. These decisions, Grupo Gigante S.A. De C.V. v. Dallo \& Co, Inc. ${ }^{13}$ and ITC, Ltd. v. Punchgini, Inc., ${ }^{14}$ respectively decided by the Second and Ninth Circuits, demonstrate the struggle to develop common law solutions in an area where globalization and movements by people pose challenges to the territoriality principle in trademark law.

\section{A. Famous Marks Doctrine and Public Policy}

In 2004, the Ninth Circuit, in Grupo Gigante v. Dallo, became the first and only appellate court to accept the famous marks doctrine as an exception to the territoriality principle. ${ }^{15}$ The court recognized the exception as a matter of sound public policy. ${ }^{16}$ The facts of Grupo Gigante unfold as follows.

In 1962, more than forty years before the litigation began, the Grupo Gigante company opened its first grocery stores in Mexico City. ${ }^{17}$ Grupo Gigante obtained trademark registration in Mexico and became a successful chain of grocery stores with 100 stores located throughout different parts of Mexico. ${ }^{18}$ In 1991, it opened six stores in Baja California, Mexico, and two in Tijuana, near the U.S.-Mexican border. ${ }^{19}$

11 Id. (noting that there is no federal trademark protection for famous foreign marks and observing that the first case that recognized the famous foreign mark in the United States was a New York state case, Maison Prunier v. Prunier's Rest. \& Café, Inc., 288 N.Y.S. 529, 535-36 (N.Y. Sup. Ct. 1936)). In Maison Prunier, the plaintiff owned "Maison Prunier," a Paris restaurant with a branch in London and brought an unfair competition action against the defendant for using the French trademark for its restaurant in New York. Id. at 535-36. The plaintiff prevailed even though it never had used the trademark in the United States. Although there was no "right to protection against the use of a trade-mark or trade name beyond the territory in which it operates," the New York court recognized "an exception to the rule" where the second user was guilty of bad faith. Id. at 557-58.

12 See Punchgini, 482 F.3d at 163 (stating that relevant provisions in the Lanham Act do not incorporate "a famous marks exception into federal unfair competition law").

${ }^{13}$ Grupo Gigante S.A. De C.V. v. Dallo \& Co., 391 F.3d 1088, 1093 (9th Cir. 2004).

${ }_{14}$ Punchgini, $482 \mathrm{~F} .3 \mathrm{~d}$ at 143.

15 Grupo Gigante, 391 F.3d at 1094 (observing that there is "no circuit-court authority-from this or any other circuit-applying a famous-mark exception to the territoriality principle").

16 Id. at 1094.

17 Id. at 1091.

${ }^{18} \mathrm{Id}$.

${ }^{19} I d$. 
In 1991, Michael Dallo selected the name "Gigante Market" for his grocery store in San Diego, and five years later, in 1996, he and his brothers opened another "Gigante Market" in the same city. ${ }^{20}$ Meanwhile, Grupo Gigante explored the possibility of expanding its grocery stores into the southern region of California and learned about the Dallos' "Gigante Market."21 Grupo Gigante met with the Dallos, but failed to persuade them to cease using the trademark "GIGANTE" for their grocery stores. ${ }^{22}$ Both Grupo Gigante and the Dallos each obtained trademark registration for GIGANTE from the state of California, but neither sought to register the mark with the United States Patent and Trademark Office. ${ }^{23}$

In 1999, Grupo Gigante opened its first U.S. GIGANTE store and followed with two more stores by 2000 in the Los Angeles area. ${ }^{24}$ Upon learning about the opening of the Gigante store, the Dallos sent a cease-and-desist letter to Grupo Gigante, demanding that Grupo Gigante stop using the GIGANTE name for its grocery stores. ${ }^{25}$ Grupo Gigante responded by filing a suit against the Dallos for improper use of its well-known GIGANTE mark protected under Articles 6 bis and 10bis of the Paris Convention, false designation of origin, and misrepresentation and unfair competition under $\S 43(\mathrm{a})$ of the Lanham Act, among other claims. ${ }^{26}$ The district court ruled in favor of Grupo Gigante and the Dallos appealed the case to the Ninth Circuit. ${ }^{27}$

At the outset, the Ninth Circuit acknowledged that the territoriality principle is the bedrock of trademark law because trademark rights exist in a country solely in accordance to that country's law. ${ }^{28}$ The territoriality principle dictates that priority of trademark rights depends upon use of the trademark in the United States and not use in other countries. Consequently, the court observed, despite the fact that Grupo Gigante had used the GIGANTE mark in Mexico for decades before the Dallos began its use of the mark in San Diego, the Dallos would have priority over Grupo Gigante in the mark GIGANTE for grocery stores in the United States. ${ }^{29}$

20 Grupo Gigante, 391 F.3d at 1091.

${ }^{21} \mathrm{Id}$.

22 Id.

${ }^{23}$ Id. at 1092-93.

${ }^{24}$ Id. at 1092 (stating that all three stores were located in the Los Angeles area and all "were called 'Gigante,' like Grupo Gigante's Mexican stores").

25 Grupo Gigante, 391 F.3d at 1092.

${ }^{26} \mathrm{Id}$. at $1093 \mathrm{n} .3$ (listing the claims brought by Grupo Gigante and the counterclaims asserted by the Dallos).

${ }^{27}$ Id. at $1092-93$.

${ }^{28} I d$. at 1093.

${ }^{29}$ Id. 
The Ninth Circuit, however, emphatically announced that "there is a famous mark exception to the territoriality principle." 30 Although the territoriality principle is a "long-standing and important doctrine" in trademark law, "it cannot be absolute." 31 The court explained that an absolute territoriality rule, without an exception for famous marks, would "promote consumer confusion and fraud." 32 It recognized that today people and commerce move across borders, and that this is especially true in the United States as a nation of immigrants. ${ }^{33}$ Because the purpose of trademark law is to protect against consumer confusion and palming off, there "can be no justification for using trademark law to fool immigrants into thinking that they are buying from the store they liked back home." 34 The appellate court then instructed the district court to apply a new standard to determine how famous a mark must be to qualify for the exception to the territoriality principle. ${ }^{35}$ In summary, the Ninth Circuit recognized the famous mark exception based on public policy.

Most importantly, the Ninth Circuit did not rely on the Paris Convention in recognizing the famous mark exception to the territoriality principle. ${ }^{36}$ Indeed, the circuit did not reference the language of any article in the Paris Convention to support its recognition of the famous marks doctrine. ${ }^{37}$ It affirmed the district court's dismissal of the plaintiff's claims of trademark rights under the Paris Convention and declared that the Paris Convention creates no "additional substantive rights" to those provided by the Lanham Act. 38 The circuit sidestepped any potential conflicts of law between the Paris Convention and the Lanham Act with respect to the famous mark exception

${ }^{30}$ Grupo Gigante, 391 F.3d at 1094.

${ }^{31} I d$.

32 Id.

${ }^{33} \mathrm{Id}$.

34 Id. at 1098 (explaining that under the new test, "a substantial percentage of consumers in the relevant American market" must be shown to have familiarity with the foreign mark and courts should consider factors such as "the intentional copying of the mark by the defendant, and whether customers of the American firm are likely to think they are patronizing the same firm that uses the mark in another country" (emphasis in original)).

35 Grupo Gigante, 391 F.3d at 1095-98 (explaining the new standard to evaluate how famous a mark must be to qualify for the exception and remanding the case back to the district court to apply the new standard).

36 The Second Circuit in Punchgini acknowledged that the Ninth Circuit in Grupo Gigante had stated that the Paris Convention does not provide any substantive protection for trademarks beyond the federal Lanham Act. ITC, Ltd. v. Punchgini, Inc., 482 F.3d 135, 162-63 (2d Cir. 2007). The Ninth Circuit's statement was important because it indicated that "marks rights are independently afforded by the Lanham Act." Id. at 163.

${ }^{37}$ Grupo Gigante, 391 F.3d at 1093-99.

${ }^{38}$ Id. at 1099-1100. The Grupo Gigante court also affirmed the district court's dismissal of the plaintiff's state law claim which does not recognize the famous marks doctrine. Id. at 1101 (observing that cases cited by plaintiff "provide no support for the conclusion that use anywhere in the world suffices to establish priority in California"). 
doctrine by formulating a new rule based solely on public policy. ${ }^{39}$ This rule was subsequently rejected by the Second Circuit three years later in ITC, Ltd. v. Punchgini, Inc. 40

\section{B. Famous Marks Doctrine and Bright-Line Rejection}

More than thirty years ago, before the Bukhara trademark dispute, the Bukhara restaurant opened in the Maurya Sheraton \& Towers, an international five-star hotel located in New Delhi. ${ }^{41}$ After the successful opening, the owners expanded the reach of the Bukhara trademark in many major cities worldwide, including Hong Kong, Bangkok, Bahrain, Montreal, Bangladesh, Singapore, Kathmandu, Ajman, New York, and Chicago. ${ }^{42}$ The London-based Restaurant magazine named Bukhara as one of the world's fifty best restaurants in $2003 .{ }^{43}$

The Bukhara restaurant opened in New York City and Chicago in 1986 and 1987, respectively. ${ }^{44}$ The owners sought and received trademark registrations for their restaurants in 1987.45 The Bukhara restaurant in Manhattan operated for five years and closed its doors in 1991.46 The Chicago Bukhara survived longer and closed down after ten years in operation, on December 17, 1997.47 As of 2004, Bukhara restaurants operated only in New Delhi, Singapore, Kathmandu, and Ajman. ${ }^{48}$

As the Bukhara restaurants began to close, the owners explored the possibility of distributing packaged, ready-to-serve foods under the Bukhara label, "Dal Bukhara," in 2001.49 In 2003, the owners began selling their food through two distributors in California and New Jersey. ${ }^{50}$ That same year, the owners exhibited their "Dal Bukhara" products at the International Fancy Foods Show in New York City. ${ }^{51}$

${ }^{39}$ Id. at $1099-1100$.

40 Punchgini, 482 F.3d at 159-60 (observing that "it appears that the Ninth Circuit recognized the famous marks doctrine as a matter of sound policy").

41 Id. at 143.

42 Id.

${ }^{43} I d$. at 143 n. 4 .

$44 \mathrm{Id}$. at 143 .

45 Punchgini, 482 F.3d at 143.

${ }^{46} I d$.

${ }^{47} \mathrm{Id}$.

48 Id.

${ }^{49} I d$.

${ }^{50}$ Punchgini, 482 F.3d at 143.

${ }^{51} I d$. 
During the same time period, Vicky Vij, a former employee at the New York Bukhara restaurant teamed up with Raja Jhanjee, Dhandu Ram, and Paragnesh Desai to open Bukhara Grill restaurants in 1999.52 Vij, Jhanjee, and Ram also previously had worked at the New Delhi Bukhara restaurant. 53 The four individuals, along with their business partners, incorporated the first company, Punchgini, to open the Bukhara Grill and the second company, Bukhara Grill II, Inc., for the opening of the second restaurant in New York City, Bukhara Grill II. 54

The defendants admitted that they purposely selected the name because the original New York Bukhara restaurant had closed. ${ }^{55}$ Defendants copied the authentic Bukhara restaurant's "logos, decors, staff uniforms, wood-slab menus, and red-checked customer bibs." ${ }^{56}$ Moreover, the defendants claimed that their Bukhara Grill restaurant "is quite like Delhi's Bukhara." 57 The opening of the Bukhara Grill attracted attention from news reporters who thought the restaurant was related to the famous Delhi's Bukhara. ${ }^{58}$

In early 2000 , counsel for the owners of the original Bukhara restaurant sent cease-and-desist letters to the defendants, demanding the defendants refrain from using the BUKHARA trademark and goodwill.59 Counsel for the defendants asserted that the owners had abandoned their trademarks in the United States. The parties corresponded but did not resolve the dispute. In early 2003, the owners of the original Bukhara restaurant brought a trademark infringement and unfair competition action under both the federal Lanham Act ${ }^{60}$ and New York state laws against the defendants. ${ }^{61}$ The district

52 Id. at 144 .

${ }^{53} I d$.

${ }^{54} I d$.

${ }^{55}$ Punchgini, 482 F.3d at 144 (noting that the defendants candidly admitted that there was then "no restaurant Bukhara in New York, and we just thought we [would] take the name").

${ }^{56} I d$.

${ }^{57}$ Id. (commenting on Jhanjee's, one of the defendants, statement about deliberate copying).

${ }^{58}$ Id. (citing to the press coverage of Bukhara Grill from Shweta Rajpal, Dal 'Bukhara' in NY: A Bukhara-Trained Trio Has Opened a Similar Restaurant in Manhattan, HINDUSTAN TIMES, May 2, 2000, and from Bob Lape, Indian Outpost Needs Dash of Spice, CRAIN'S N.Y. BUS., Dec. 13-19, 2000, which noted "name similarity between Bukhara Grill and [the] former New York Bukhara").

${ }^{59} \mathrm{Id}$. at 144 .

6o Punchgini, 482 F.3d at 154. Under $\$ 43(a)(1)(A)$ of the Lanham Act, the plaintiff can bring an action against the defendant who uses "any word, term name, symbol, or device, or any combination there of . . which . . . is likely to cause confusion ... as to the origin, sponsorship, or approval of [the producer's] . . services." 15 U.S.C. $\S 1125(a)(1)(A)$. A $\S 43(a)(1)(A)$ claim is broader than the protection afforded under a $\S 32(1)$ (a) trademark infringement claim. Section 43(a) protects unregistered trademarks. See Two Pesos v. Taco Cabana, 505 U.S. 763, 768 (1992) ("Section 43(a) prohibits a broader range of practices than does $\S 32$, which applies to registered marks, but it is common ground that $\S 43$ (a) protects qualifying unregistered trademarks.") (citation omitted). 
court granted defendants' summary judgment motion, finding that the plaintiffs could not sustain their claims because they had abandoned their BUKHARA trademark for restaurants in the United States. ${ }^{62}$

To overcome the defense of abandonment, the plaintiffs rested their case on the famous marks doctrine. ${ }^{63}$ The plaintiffs urged the Second Circuit to recognize that their BUKHARA mark was famous and that they had priority over the defendants in the trademark. ${ }^{64}$ They asserted that they had continuously used and branded their BUKHARA trademark in the last thirty years in many countries and that their trademark was renowned in the United States before the defendants deliberately copied the Bukhara name and restaurant trade dress for their Bukhara Grill in New York City. ${ }^{65}$

The Second Circuit in ITC Ltd. v. Punchgini, Inc. flatly rejected the famous marks doctrine.66 The Punchgini court noted that although the Second Circuit had made references to the famous marks doctrine on two occasions, neither of the two prior decisions required the court to determine whether it must apply the doctrine. ${ }^{67}$ The court observed that the Ninth Circuit was the only federal appellate court that had recognized the famous marks doctrine "as a matter of sound policy," and it declined to follow the Ninth Circuit. 68 The Second Circuit explained that the international treaties for the protection of famous marks, the Paris Convention and TRIPs, are not self-executing and the Lanham Act remains the federal law governing whether the owners of the original BUKHARA trademark have priority rights in the United States. ${ }^{69}$ The court examined relevant provisions under the Lanham Act and held that they did not expressly incorporate the famous

${ }^{61}$ Punchgini, 482 F.3d at 145.

62 Id. (citing ITC, Ltd. v. Punchgini, Inc., 373 F. Supp. 2d 275 (S.D.N.Y. 2005)).

${ }^{63} \mathrm{Id}$. at $156-58$.

64 Id. at 156 (stating that the plaintiff urged the court to "recognize an exception to the territoriality principle for those foreign marks that, even if not used in the United States by their owners, have achieved a certain measure of fame within this country").

65 Id. at 154.

${ }^{66}$ Punchgini, 482 F.3d at 164 (declining to construe the Lanham Act to allow the famous mark doctrine as an exception to the territoriality principle and waiting "for Congress to express its intent" on the departure).

${ }^{67} \mathrm{Id}$. at 160 (noting that the decision in Buti v. Impressa Perosa, S.R.L., 139 F.3d 98, 104 n.2 (2d Cir. 1998), concluded that the "famous marks doctrine has no application here given that Impressa has made no claim under that doctrine" and that Empresa Cubana del Tabaco v. Culbro Corp., 399 F.3d 462, 481 (2d Cir. 2005), declined to decide whether the famous marks doctrine should be recognized because "even assuming that the famous marks doctrine is otherwise viable and applicable, the [Cuban] embargo bars [plaintiff] from acquiring property rights in the ... mark through the doctrine") (citation omitted).

${ }^{68}$ Id. at $159-60$.

${ }^{69} \mathrm{Id}$. at 162 (asserting that the Second Circuit had "expressly held that the Paris Convention creates no substantive United States rights beyond those independently provided in the Lanham Act" in Empresa Cubana del Tabaco v. Culbro Corp., 399 F.3d 462, 485 (2d Cir. 2005)). 
marks doctrine or the protection for famous marks stated in Article 6bis of the Paris Convention and Article 16(2) of TRIPs. ${ }^{70}$

The Second Circuit explicitly declined the plaintiffs' invitation to adopt a policy-based approach for judicial recognition of the famous marks doctrine under federal law. ${ }^{71}$ It noted that policy arguments can be persuasive at times, but in the context of the Lanham Act, which is comprehensive and frequently amended by Congress, it is not appropriate for the judiciary to recognize the famous marks doctrine as an exception to the territoriality doctrine. ${ }^{72}$ Congress is the body to decide "whether and under what circumstances to accord federal recognition to such an exception to the basic principle of territoriality."73

The Second Circuit's decision in Punchgini and the Ninth Circuit's decision in Grupo Gigante epitomize the two opposite views on U.S. protection for famous foreign trademarks. Punchgini represents a steadfast adherence to the U.S. use requirement in U.S. territory while ignoring the fame of the foreign trademark. Grupo Gigante recognizes the fame of the foreign trademark transmitted through the migration of people who recognize and expect consistency from the mark, even though there is no use of that particular mark within U.S. territory. Both decisions demonstrate how U.S. courts struggle with fame, use, and territoriality in addressing trademarks in the age of increasing globalization. ${ }^{74}$

${ }^{70} \mathrm{Id}$. at $162-63$. The court remarked that it was "mindful" that its conclusion is contrary to the leading commentator's position on famous marks doctrine. Id. at 163 (disagreeing with Professor McCarthy's conclusion that "both the TRIPs Agreement and the Paris Convention Article 6bis require the United States to recognize rights in famous foreign marks, even if they have not been registered or used in the United States") (citation omitted).

${ }^{71}$ Punchgini, 482 F.3d at 165 ("The fact that a doctrine may promote sound policy, however, is not a sufficient ground for its judicial recognition, particularly in an area regulated by statute.").

72 Id.

${ }^{73} \mathrm{Id}$.

74 The Second Circuit, after affirming the district court's summary judgment in favor of the defendants on the federal and state trademark infringement claims and the federal unfair competition claim, certified two questions to the New York Court of Appeals because the Second Circuit "recognized the possibility that the famous marks doctrine might support a New York common law claim for unfair competition." ITC, Ltd. v. Punchgini, Inc., 518 F.3d 159, 160 (2d Cir. 2008). The two certified questions were: (1) "Does New York common law permit the owner of a federal mark or trade dress to assert property rights therein by virtue of the owner's prior use of the mark or dress in a foreign country?"; and (2) "If so, how famous must a foreign mark be to permit a foreign mark owner to bring a claim for unfair competition?" Id. The New York Court of Appeals responded that to pursue an unfair competition claim under New York law, the plaintiffs must establish both deliberate copying and secondary meaning. See ITC, Ltd. v. Punchgini, Inc., 880 N.E.2d 852, 859-60 (N.Y. 2007); see also Punchgini, 518 F.3d at 161. Upon receiving the responses from the New York Court of Appeals, the Second Circuit affirmed the district court's award of summary judgment in its entirety. ITC, Ltd. v. Punchgini, Inc., 518 F.3d 159 (2d Cir. 2008). 


\section{FAME, USE, AND TERRITORIALITY}

\section{A. Use and Territoriality: Forget Fame}

Both the Second and the Ninth Circuits agreed that the territoriality principle is fundamental to trademark rights. They agreed that under the territoriality principle, without use of the foreign trademark in the United States, there will be no trademark rights. ${ }^{75}$ There are numerous possible examples of trademark use. ${ }^{76}$ Obviously, having the mark affixed to products in the stream of commerce constitutes use. ${ }^{77}$ Also, having a website with the mark as a source identifier for the content provided at the website constitutes use. ${ }^{78}$ Even mere advertisement of the trademark in the United States while offering the actual products for sale outside the United States also may satisfy the use requirement. ${ }^{79}$ Whoever uses the mark first will have priority. ${ }^{80}$ Whoever files an intent-to-use federal trademark application first also can claim priority. ${ }^{81}$ Without either using the mark or filing an intent-touse application, a trademark owner cannot establish priority. The territoriality of trademark rights requires all domestic and foreign trademark owners to follow U.S. law if they want to avail themselves of its protection for their trademarks.

Both the Second and Ninth Circuits also agree that the Paris Convention does not provide additional substantive trademark rights and that the Lanham Act remains the governing law for trademark rights in the United States. ${ }^{82}$ Article $6 b i s$ of the Paris Convention provides a famous mark

${ }^{75}$ Id. at 155-56; Grupo Gigante S.A. De C.V. v. Dallo \& Co., 391 F.3d 1088, 1093 (9th Cir. 2004),

${ }^{76}$ In order to be qualified as trademark use, the use must be lawful. See CreAgri, Inc. v. USANA Health Scis., Inc., 474 F.3d 626, 630 (9th Cir. 2007) (stating that "use in commerce only creates trademark rights when the use is lawful") (emphasis in original).

77 See Graeme B. Dinwoodie \& Mark D. Janis, Confusion Over Use: Contextualism in Trademark Law, 92 IOWA L. REV. 1597, 1643 (2007) (discussing actual use and "token uses" of trademarks).

78 Other examples of trademark use to establish priority under trademark law include prior use of a term in advertising brochures, catalogues, newspapers, press releases, and trade publications. See Malcolm Nicol \& Co. v. Witco Corp., 881 F.2d 1063, 1065 (Fed. Cir. 1989).

79 See generally Int'l Bancorp, L.L.C. v. Societe des Bains de Mer et du Cercle des Estrangers a Monaco, 329 F.3d 359 (4th Cir. 2003). The dissenting opinion strongly opposed the majority's ruling on "use in commerce" based on mere advertisement and lack of use of the mark in the United States. Id. at 383.

80 See Starbucks U.S. Brands, L.L.C. v. Ruben, 78 U.S.P.Q.2d (BNA) 1741, 1750 (T.T.A.B. 2006) (noting the priority of the trademark owner in its various STARBUCKS marks prior to the "filing date of applicant's application, which in the absence of other evidence, is the earliest date on which applicant can rely").

${ }^{81}$ In cases where neither party can establish priority of registration or use of the trademarks, the parties' application filing dates are crucial in determining priority. See Aktieselskabet af 21. Nov. 2001 v. Fame Jeans, Inc., 77 U.S.P.Q.2d (BNA) 1861, 1864 (T.T.A.B. 2006) (parties' application filing dates control the determination of priority).

82 ITC, Ltd. v. Punchgini, Inc., 482 F.3d 135, 162-65 (2d Cir. 2007), cert. denied, 128 S. Ct. 288 (2007); Grupo Gigante S.A. De C.V. v. Dallo \& Co., 391 F.3d 1088, 1100 (9th Cir. 2004). 
exception protection, but the Paris Convention itself only dictates signatory members to provide national treatment. ${ }^{83}$ The Lanham Act complies with the Paris Convention by treating domestic and foreign trademark owners the same. Foreign trademark owners must follow the Lanham Act just as domestic trademark owners do in order to receive trademark protection. The Lanham Act imposes the use requirement on both domestic and foreign trademark owners. ${ }^{84}$ That means that the territoriality principle governs trademark rights in the United States.

The circuits' views on the territoriality principle, however, divert from here. The Second Circuit took the view that regardless of the fame a foreign trademark has attained outside the United States, if the foreign trademark is not in use here, than no trademark rights exist in the United States. ${ }^{85}$ Also, if the owner of the famous foreign trademark used the mark in the United States for a period of time, but then ceased to use it in the United States while continuing to use it outside the United States, no trademark rights exist here since the owner abandoned the mark. ${ }^{86}$ Under the Second Circuit's rule, the territoriality principle is absolute. There is no exception to the principle. Regardless of the trademark's fame outside and inside the United States, no use means no rights.

The Ninth Circuit has an entirely different view. The Ninth Circuit's approach that "territoriality . . . cannot be absolute" means that use of the mark in the United States is not required for protection ${ }^{87}$ as long as the mark itself, through use outside the United States, is known by people in the United States. 88

Indeed, if the foreign trademark is known by people in the United States who believe that the American junior user's mark is the same as a foreign trademark, an exception to the territoriality principle applies. ${ }^{89}$ In other

83 Id. at 162-63 (discussing "national treatment" requirement and citing to Grupo Gigante for its statement on affirming that the Lanham Act, not the Paris Convention, is the law).

84 Id. at 162 ("National treatment means that foreign nationals should be given the same treatment in each of the member countries as that country makes available to its own citizens. So, section 44 of the Lanham Act gives foreign nationals the same rights and protections provided to United States citizens by the Lanham Act.").

${ }^{85} \mathrm{Id}$. at 155 (stating that without use "of its mark in the United States, a foreign mark holder generally may not assert priority rights under federal law, even if a United States competitor has knowingly appropriated that mark for his own use"). Cf. Section 44(e) of the Lanham Act, however, provides for registration of a foreign mark that has been registered in the home country, as long as the application indicates the applicant's bona fide intention to use the foreign mark in commerce in the United States, "but use in commerce shall not be required prior to registration." 15 U.S.C. \$1126(e) (2006).

${ }^{86}$ Grupo Gigante, 391 F.3d at 153 (affirming the defendant's abandonment defense).

87 Id. at 1094.

88 Id.

${ }^{89}$ Id. 
words, if the fame of the foreign trademark reaches the United States because of people migrating across national borders, the trademark remains protected, in order to prevent confusion as to the source. The fame of the trademark, according to the Ninth Circuit, is not the typical fame in the federal trademark dilution law, based on years of sales of goods or extensive advertisements bearing the trademark in the United States. 90 The concept of fame, as recognized by the Ninth Circuit, depends on the movements of the people who recognize the mark. ${ }^{91}$

The Ninth Circuit relies on the main purpose of trademark law, protecting consumers from source confusion, but allows the law to bend the territoriality principle. However, its approach necessitates an extensive factual inquiry as to fame. How famous must a foreign mark be in order to justify a departure from the territoriality principle? What is the standard to measure fame? Should the fame of the foreign mark for the territoriality exception require niche fame or a heightened level of fame as required under the federal trademark antidilution law? We turn now to these questions.

\section{B. Forget Use and Territoriality, but Retain Fame}

Generally, a trademark garners its fame through extensive sales and advertisement of the goods in commerce. Over time, the consuming public may come to recognize the trademark within a particular industry or a

90 For examples of niche fame requiring substantial sales and advertisements, see generally Nina Ricci, S.A.R.L. v. E.T.F. Enters., Inc., 889 F.2d 1070, 1074 (Fed. Cir. 1989) (NINA RICCI mark, known for perfume, clothing, and accessories, was deemed famous within its niche based on $\$ 200$ million in sales, $\$ 37$ million in advertising, and more than 27 years of use); Kimberly-Clark Corp. v. H. Douglas Enter., Ltd., 774 F.2d 1144, 1145-46 (Fed. Cir. 1985) (stating the fame of HUGGIES trademark, known for its diapers, was based on $\$ 300$ million of sales in a nine-year period and annual advertisements of $\$ 15$ million); Specialty Brands, Inc. v. Coffee Bean Distribs., Inc., 748 F.2d 669, 674 (Fed. Cir. 1984) (noting that the SPICE ISLANDS trademark for teas, spices, and seasonings was in use for forty years and garnered sales of $\$ 25$ million annually); Giant Food, Inc. U. Nation's Foodservice, Inc., 710 F.2d 1565, 1571 (Fed. Cir. 1983) (stating that the fame of the trademark GIANT FOOD, known for supermarkets, was based on sales over $\$ 1$ billion annually and its use for forty-five years).

91 The Ninth Circuit provided an example about fame dependent on the movement of the people as follows:

It might not matter if someone visiting Fairbanks, Alaska from Wellington, New Zealand saw a cute hair-salon name-"Hair Today, Gone Tomorrow," "Mane Place," "Hair on Earth," "Mary's Hair'em," or "Shear Heaven"-and decided to use the name on her own salon back home in New Zealand. The ladies in New Zealand would not likely think they were going to a branch of a Fairbanks hair salon. But if someone opened a high-end salon with a red door in Wellington and called it Elizabeth Arden's, women might very well go there because they thought they were going to an affiliate of the Elizabeth Arden chain, even if there had not been any other Elizabeth Ardens in New Zealand prior to the salon's opening. If it was not an affiliate, just a local store with no connection, customers would be fooled. The real Elizabeth Arden chain might lose business if word spread that the Wellington salon was nothing special. 
region. This means, through use, the trademark has achieved fame within a niche. To qualify for antidilution protection, however, a trademark must achieve national fame, not just niche fame. ${ }^{92}$ That is, the consuming public nationwide must recognize the trademark in order for the trademark owner to gain antidilution protection against a junior user of an identical or similar trademark that causes tarnishment or blurring. ${ }^{93}$

In light of the fame requirement under the Federal Trademark Dilution Revision Act of 2006, should the same standard be applied to famous foreign mark exceptions to the territoriality principle? Before exploring possible answers to this question, the famous mark exception to the territoriality must first be recognized, as announced by the Ninth Circuit in Grupo Gigante. In other words, use in the United States is not of concern, and fame becomes the main inquiry.

The Ninth Circuit ruled that when foreign use of a mark achieves a certain level of fame within the United States, the territoriality principle does not bar that mark from claiming priority over the earlier foreign use. ${ }^{94}$ Yet, how is fame measured in this context? The district court applied the secondary meaning test and found that the GIGANTE mark had achieved secondary meaning in the geographical area where the plaintiff wished to assert protection. ${ }^{95}$ The Ninth Circuit rejected the district court's approach, stating that "secondary meaning is not enough" and ruled that additional tests are required in order for the foreign trademark to qualify as an exception to the territoriality principle. ${ }^{96}$

92 See 15 U.S.C. $\$ 1125$ (c)(2)(A) (2006) (defining a famous trademark as one that "is widely recognized by the general consuming public of the United States as a designation of source of the goods or services of the mark's owner"). See also Top Tobacco, L.P. v. North Atlantic Operating Co., Inc., 509 F.3d 380 (7th Cir. 2007).

${ }^{93}$ In considering whether a mark is famous for the federal trademark antidilution protection, courts may consider the following factors:

(i) The duration, extent, and geographic reach of advertising and publicity of the mark, whether advertised or publicized by the owner or third parties.

(ii) The amount, volume, and geographic extent of sales of goods or services offered under the mark.

(iii) The extent of actual recognition of the mark.

(iv) Whether the mark was registered under the Act of March 3, 1881, or the Act of February 20, 1905, or on the principal register.

15 U.S.C. $\S 1125$ (c)(2)(A) (2006); see also Nike, Inc. v. Nikepal Intern., Inc., No. 2:05-cv-1468GEB-JFM, 2007 WL 2688499 (E.D. Cal. Sept. 10, 2007) (finding the NIKE trademark famous as it is widely recognized by the general consuming public).

94 Grupo Gigante, 391 F.3d at 1095-98 (discussing how fame must be established in the United States and factors for consideration).

${ }^{95} I d$. at 1095 (noting that the district court held that "the correct inquiry . . . was to determine whether the mark had attained secondary meaning in the San Diego area").

${ }^{96}$ Id . at 1098. 
The Ninth Circuit ruled that when a foreign mark has never been used in the United States, the trademark holder must establish that "a substantial percentage of consumers in the relevant American market is familiar with the foreign mark." 97 The relevant American market is the geographic area where the defendant uses the trademark. ${ }^{98}$ The Ninth Circuit instructed that the district court should consider factors related to consumer confusion and fraud, such as the intentional copying of the mark by the defendant and the likelihood that the defendant's customers think that they are "patronizing the same firm that uses the mark in another country." 99

The "substantial percentage" phrase, however, leaves wide open for interpretation the precise meaning of the requirement. Does it mean less than 20 percent, 50 percent, or more than 50 percent? Even if the "substantial percentage" means more than 50 percent, the fame requirement for the exception to the territoriality principle, as announced by the Ninth Circuit, is only niche fame because it is known only within the relevant geographic area where the U.S. company uses the foreign trademark. The mark need not be known to the general consuming public. That means the requirement is higher than necessary for protection in a domestic trademark infringement and unfair competition case. On the other hand, that also means the requirement is lower than the level of fame required for the trademark antidilution protection. The requirement is an intermediate level of fame.

Consequently, the "substantial percentage" of consumers in the relevantmarket requirement may be established mainly by survey evidence of recognition, rather than by use of the trademark in the United States. The public perception in the relevant U.S. market without the trademark owner's actual use of the trademark in commerce means that the traditional usebased proof-such as evidence of sales of products in the United States, advertisements of the products in the United States, and market expansion history in the United States-are not available.

\section{Conclusion: A Legislative, Not Judicial, Solution}

The Second and Ninth Circuits' conflicting decisions on the famous marks doctrine exception to the territoriality principle may lead one to speculate that the United States Supreme Court may accept a certiorari petition to address the issue. Although the Court has been eager to hear other types of intellectual property cases, such as patent cases, and to overturn the Federal Circuit's decisions, it has declined to accept certiorari for ITC Ltd. v.

\footnotetext{
${ }^{97} I d$. (emphasis in original).

98 Id.

99 Grupo Gigante, 391 F.3d at 1098.
} 
Punchgini, Inc.. ${ }^{100}$ The Supreme Court was wise to deny the certiorari petition.

Congress can best address the issue of whether the Lanham Act should be amended to provide recognition of famous foreign marks. Currently, U.S. trademark law is at odds with numerous countries that recognize and incorporate the famous marks doctrine into their trademark law. ${ }^{101}$ Understanding the influence of trademark owners on the direction of trademark law in the United States, Congress most likely will not tackle the famous marks doctrine if the International Trademark Association ("INTA") does not initiate the amendment efforts and endorse it. ${ }^{102}$ INTA may not express interest in having U.S. law provide an exception to the territoriality principle because owners of known global trademarks have already registered their marks in the United States, and the United States is a large and important market of foreign goods and services. The fact that the famous marks doctrine has not become an important issue of concern to trademark owners for more than sixty years may reinforce the belief that the Lanham Act, as amended numerous times, does not need to address the famous marks doctrine. ${ }^{103}$

INTA, as the largest organization of trademark owners worldwide, ${ }^{104}$ and Congress should study and decide whether to amend the Lanham Act to accept the famous marks doctrine. Cases in the Trademark Trial and Appeal Board, state courts, and federal courts all encounter the famous marks doctrine. Most federal decisions avoided addressing the doctrine directly. ${ }^{105}$ As the Second Circuit in Punchgini noted, every lower court or state court recognizing the doctrine has based its decision mainly on state common law. ${ }^{106}$ Cases with claims based on the famous marks doctrine, however, will

100 ITC, Ltd. v. Punchgini, Inc., 482 F.3d 135, 157 (2d Cir. 2007), cert. denied, 128 S. Ct. 288 (2007).

101 Bruce J. Goldner \& Kenneth A. Plevan, Circuit Split on Famous Marks: With Recent Denial of Certiorari, Two Circuits Remain at Odds Over Mark Rights Without Local Usage, NAT'L L.J., Oct. 29, 2007, at S1 ("If Punchgini is upheld, the United States will be out of step with many other jurisdictions, such as France, Spain, and Italy, that, based on Article 6bis of the Paris Convention, incorporate the famous marks doctrine explicitly into their trademark statutes."); see also Weissberger, supra note 5, at 768 (noting that China, Brazil, and South Africa extend protection to unregistered famous foreign marks).

102 Goldner \& Plevan, supra note 101, at S1. (stating that Congress' interest in addressing the famous marks doctrine is dependent on INTA's level of interest).

103 The first case decided on the famous marks doctrine was Maison Prunier $v$. Prunier Rest. \& Café, 288 N.Y.S. 529 (N.Y. Sup. Ct. 1936); see also ITC, Ltd. v. Punchgini, Inc., 482 F.3d 135, 157-61 (2d Cir. 2007) (reviewing state and federal actions related to the famous marks doctrine).

${ }^{104}$ INTA has more than 5500 members in 190 countries. Int'l Trademark Ass'n, About INTA, http://www.inta.org/index.php?option=com_content\&task=view\&id=14\&Itemid=37\&getcontent= 4 (last visited Apr. 2, 2008).

105 See Punchgini, 482 F.3d at 157-61 (noting that no federal tribunal or court had directly recognized the famous marks doctrines until the Grupo Gigante decision).

106 Id. at $157-58$. 
not go away, particularly now that the Ninth Circuit explicitly has recognized the doctrine as an exception to the territoriality principle as a matter of sound public policy.

Cases with claims based on the famous marks doctrine will appear again and perhaps with more frequency in the future. International travel has become common today, and people move with ease from one country to the next. People travel for permanent and temporary employment, crossing national borders frequently. Moreover, in the age of the internet, people move in cyberspace, with several billion websites allowing internet users to cross invisible national borders to conduct communication and transact businesses with a click of a mouse. ${ }^{107}$ Consequently, the famous marks doctrine exception becomes more appealing to protect consumers from being misled as to the source of the goods or services offered in connection with a mark known outside the physical space of the United States. 108

\footnotetext{
${ }^{107}$ A reference indicates that there are more than five billion websites, excluding MySpace pages and Google pages. WikiAnswers, What Is the Total Number of Websites?, http://wiki.answers.com/ Q/What_is_the_total_number_of_websites (last visited Apr. 2, 2008).

108 See De Beers L.V. Trademark, Ltd. v. Rosenblatt, No. 04 CIV. 4099 (DLC), 2005 U.S. Dist. Lexis. 9307 , at ${ }^{*} 25$ (S.D.N.Y. May 19, 2005) (U.K. plaintiffs brought suit against a U.S. company alleging violation of their trademark, noting that "[r]ecognition of the famous marks doctrine is particularly desirable in a world where international travel is commonplace and where the Internet and other media facilitate the rapid creation of business goodwill that transcends borders").
} 